\title{
Land Suitability for Sustainable Rubber Cultivation in Moneragala District
}

\author{
L. Samarappuli ${ }^{1}$, W. Wijesuriya ${ }^{2, \#, ~ D . ~ M . ~ A . ~ P . ~ D i s s a n a y a k e ~}{ }^{3}$, \\ S. B. Karunaratne ${ }^{4}$ and H. M. L. K. Herath ${ }^{4}$ \\ ${ }^{1}$ Export Development Board, Colombo, Sri Lanka \\ ${ }^{2}$ Rubber Research Institute of Sri Lanka, Dartonfield, Agalawatta, Sri Lanka \\ ${ }^{3}$ Rubber Research Institute of Sri Lanka, Telewala Road, Ratmalana \\ ${ }^{4}$ Wayamba University of Sri Lanka, Makandura, Gonawila (NWP)
}

${ }^{\#}$ Corresponding Author:

E-mail: wasanawij@hotmail.com

\begin{abstract}
With respect to rainfall, the current rubber growing areas are suitable for rubber planting. However, the DS divisions, Kataragama, Tanamalwila and Siyambalanduwa are relatively drier. Nearly, $97 \%$ of the land extent in the district has a mean annual temperature between $23^{\circ} \mathrm{C}$ to $27^{\circ} \mathrm{C}$, which is desirable for rubber. Majority of the land area (67\%) belongs to the elevation category below $200 \mathrm{~m}$ above mean sea level. Most of the lands belong to the slope category of less than $20 \%$ which is desirable and only $1 \%$ of the lands belong to greater than $45 \%$ slope. There is no limitation with respect to rockiness in the selected sites of Moneragala district. Water tables less than $1 \mathrm{~m}$ were not observed in any of the locations. The soil depth is found in the desirable range $(>1 \mathrm{~m})$. The $\mathrm{pH}$ levels are well within the desirable range of 4 to 6 . Yet, the observed organic matter content $(O M C)$ was found in the limiting range. The study identified the available lands, viz. barren lands, grasslands, shrub lands and under- utilized lands through GIS approach and nearly 6\% (34,752 ha) of the identified land can be categorized under most suitable lands for cultivation of rubber in the Moneragal district.
\end{abstract}

KEYWORDS: Land suitability, Rubber, GIS

\section{Introduction}

Increasing productivity and extent under cultivation are the two possible solutions to achieve the national targets in the rubber sector. However, declining rubber extent is an issue of national concern to Sri Lanka. This is mainly due to change in land use that took place in traditional rubber growing areas in the wet zone of Sri Lanka. Further, new planting programmes in these areas remain at a very low level 
due to non-availability of land. The state response towards this issue was a very positive one, giving emphasis on non-traditional rubber growing area in Moneragala district where land and labour are assumed to be non-limiting factors. If properly implemented, the rubber planting programmes in these areas will probably fit into two of the themes in Millennium Development Goals (MDGs); poverty alleviation and environmental sustainability.

In Sri Lanka, rubber (Hevea brasiliensis) grows on a broad spectrum of edaphic and physiographic situations. These situations range from flooded or muddy soils along riversides to well drained uplands or steep lands with variable soil conditions. Yet, the performance and economic viability of rubber plantations can be affected severely due to a limitation of a particular land or soil characteristic. Under such limiting conditions intensive and costly soil management practices have to be carried out to ensure higher growth and yield levels. In the present circumstances, with high production costs, the adoption of such expensive agro-management practices seems to be uneconomical. In the height of this, rubber should be planted only on lands with acceptable level of slope and soil characteristics. Therefore, the selection of suitable lands with proper soil characteristics is considered as a key factor to ensure high returns on investment.

This paper assesses land slope, rockiness, drainage and water table, soil depth, soil texture, soil $\mathrm{pH}$ and soil organic carbon in selecting suitable land for rubber plantations in the non-traditional rubber growing areas in Moneragala district.

\section{Materials and Methods}

\section{Description of the Study Area}

Rubber is found in 8 out of 11 Divisional Secretariat (DS) divisions in the Moneragala district. This study covered 7 DS divisions in Moneragala district and the study sites in Moneragala district are listed in Table 1.

\section{Assessing Land Suitability for Rubber Cultivation}

Land slope, Rockiness, Drainage and water table, Soil depth, texture, soil pH, soil organic carbon and soil nutrient status were monitored in representative study sites in Moneragala district.

\section{Questionnaire survey}

Questionnaires were designed and prepared to gather information on land and soil aspects of smallholder rubber lands in Moneragala district. A total of 255, 248 and 143 rubber farmers were interviewed during the study in 2009/2010 in the respective categories of 'potential' (those who have prepared lands for rubber cultivation) and those who own immature and mature plantations. 
Table 1: Study sites in different DS divisions of Moneragala district

\begin{tabular}{cc}
\hline Divisional Secretariat & Sites \\
\hline Badalkumbura & Lunugala Kolaniya, Kotamuduna, \\
Moneragala & Karawila Karandagama, Madugahapattiya, Hela Thunkala \\
Bibila & Radaliedda, Pitakumbura, Badullegammana \\
Medagama & Polgahapitiya, Rathhanadeniya \\
Wellawaya & Siyambalagune \\
Buttala & Yudaganawa \\
Madulla & Kolladeniya \\
\hline
\end{tabular}

\section{Results and Discussion}

\section{Land Availability for Rubber Cultivation in Moneragala District}

According to the survey done in 2001 by the Land Use Planning Division, Moneragala, 22533 ha of land is available for rubber cultivation as indicated in Table 2.

Table 2: Land availability for rubber cultivation in the Moneragala district according to agro-ecological regions

\begin{tabular}{lllc}
\hline & \multicolumn{1}{c}{ DS Division } & Agro-Ecological Region & Extent (ha) \\
\hline 01 & Badalkumbura & IM2b, IL1c & 4114 \\
02 & Bibila & IL1c, IL2 & 2836 \\
03 & Buttala & IL1c & 488 \\
04 & Moneragala & IM2b, IL1c & 3553 \\
05 & Madulla & IL2 & 3116 \\
06 & Siyambalanduwa & IL2 & 2296 \\
07 & Medagama & IM2b, IL1c & 5516 \\
08 & Wellawaya & IM2b, IL1c & 614 \\
\hline \multicolumn{2}{r}{ Total } & & 22533 \\
\hline
\end{tabular}

Source: Land Use and Planning Division, Moneragala, 2003.

This is out of a total of 215723 ha of cultivable land as listed in Table 3. Out of the identified 22533 ha, 6443 ha are unused state owned land. Further, 8057 ha of improperly utilized or abandoned lands given for families on Swarnabhoomi /Jayabhoomi deeds are also available for rubber cultivation. As per these statistics, it can be seen that MRDP will not face any difficulty in finding land. The details of distribution of rubber lands at present in non-traditional rubber growing areas are given in Table 4. 
Table 3: Total cultivable land in Moneragala district - 1998

\begin{tabular}{|c|c|}
\hline Type of Land & Extent (ha) \\
\hline Open forests & 50113 \\
\hline Shrub jungle & 77049 \\
\hline Chena land & 77491 \\
\hline Grass land & 11070 \\
\hline Total & 215723 \\
\hline
\end{tabular}

Source: Land Use and Planning Division, Moneragala, 2003.

Table 4: Distribution of rubber lands in Moneragala district

\begin{tabular}{lcc}
\hline \multicolumn{1}{c}{ DS Division } & Rubber Extent (ha) & Rank \\
\hline Badalkumbura & 2939.51 & 1 \\
Moneragala & 1203.98 & 2 \\
Bibila & 927.40 & 3 \\
Medagama & 748.65 & 4 \\
Wellawaya & 295.85 & 5 \\
Buttala & 167.65 & 7 \\
Madulla & 196.76 & 6 \\
Siyambalanduwa & 47.35 & 8 \\
\hline \multicolumn{2}{c}{ Total } & 6527.15 \\
\hline
\end{tabular}

\section{Previous Crop}

Sugarcane and Banana were the major crops grown previously in rubber lands (Figure 1). A considerable percentage of lands were shrub jungles before. Other crops which occupied included; corn, lime, chilies, pepper, timber, coconut, manioc and chena cultivations.

\section{Rainfall}

Rainfall plays a vital role in growth and development of the rubber plant. Hence, it is essential to identify areas which are vulnerable to adverse weather conditions to suggest appropriate agro-management practices to overcome such situations. In order to meet these requirements spatio-temporal maps of the distribution of rainfall in the Moneragala district were derived with the aid of GIS.

The spatial distribution of mean annual rainfall is presented in Figure 2. For a healthy growth of the rubber tree, annual cumulative rainfall should be between $1650 \mathrm{~mm}$ to $3000 \mathrm{~mm}$ (Yogaratnam, 2001). A rainfall less than $1650 \mathrm{~mm}$ will retard the growth and more than $3000 \mathrm{~mm}$ will result in spread of diseases which cause economic losses to the rubber plantations. Results revealed that most of the parts of the Moneragala districts receive more than $1650 \mathrm{~mm}$ of annual cumulative rainfall. 
This suggests that most parts of the district are suitable for rubber by considering the cumulative annual rainfall. Areas in the southern part of the district (Figure 3) recorded a rainfall less than $1650 \mathrm{~mm}$ and are not suitable for rubber. Further, GIS results indicated that an extent of 2,340,354 ha (74\%) of the district receives more than $1650 \mathrm{~mm}$ of annual rainfall while 835,146 ha $(26 \%)$ receive less than 1650 $\mathrm{mm}$.

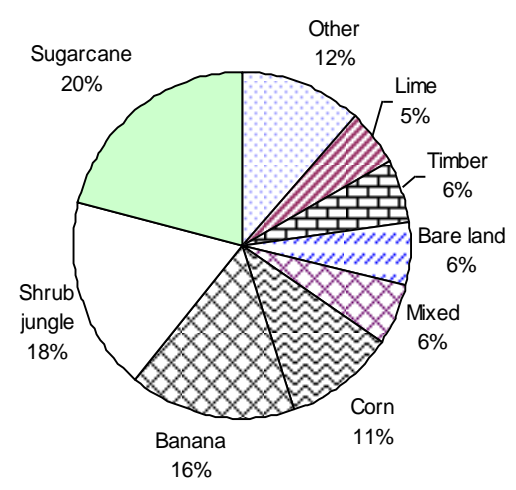

(A)

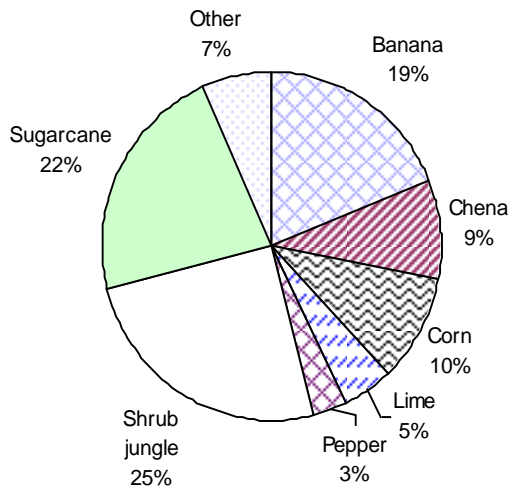

(B)

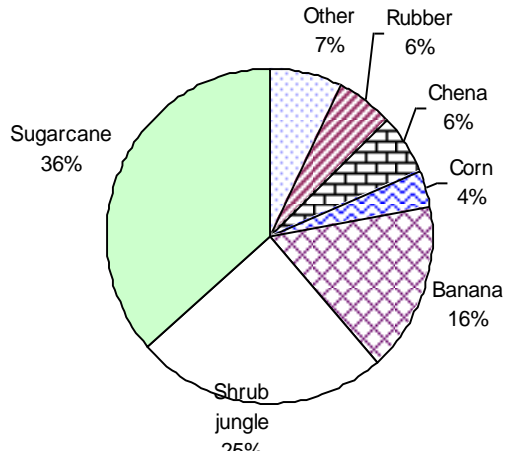

(C)

Figure 1: Previous crop in lands of (A) 'potential' rubber growers

(B) immature lands, and (C) mature lands

Though rubber can be grown over $1650 \mathrm{~mm}$ of annual rainfall it is important to note that growth of the plant is severely affected if the rainfall is less than $500 \mathrm{~mm}$ in 6 consecutive months (Yogaratnam, 2001). In order to assess this requirement, a spatial analysis was conducted for the Moneragala district. Results revealed that July to December, August to January, September to February, October to March and November to April recorded a rainfall more than $500 \mathrm{~mm}$ over 6 consecutive months for the whole of Moneragala district. The period, January to June in the DS division Kataragama receives less than $500 \mathrm{~mm}$. Also most parts of the DS division, Kataragama and part of the Tanamanwila DS division receive less than $500 \mathrm{~mm}$ during February to July. 


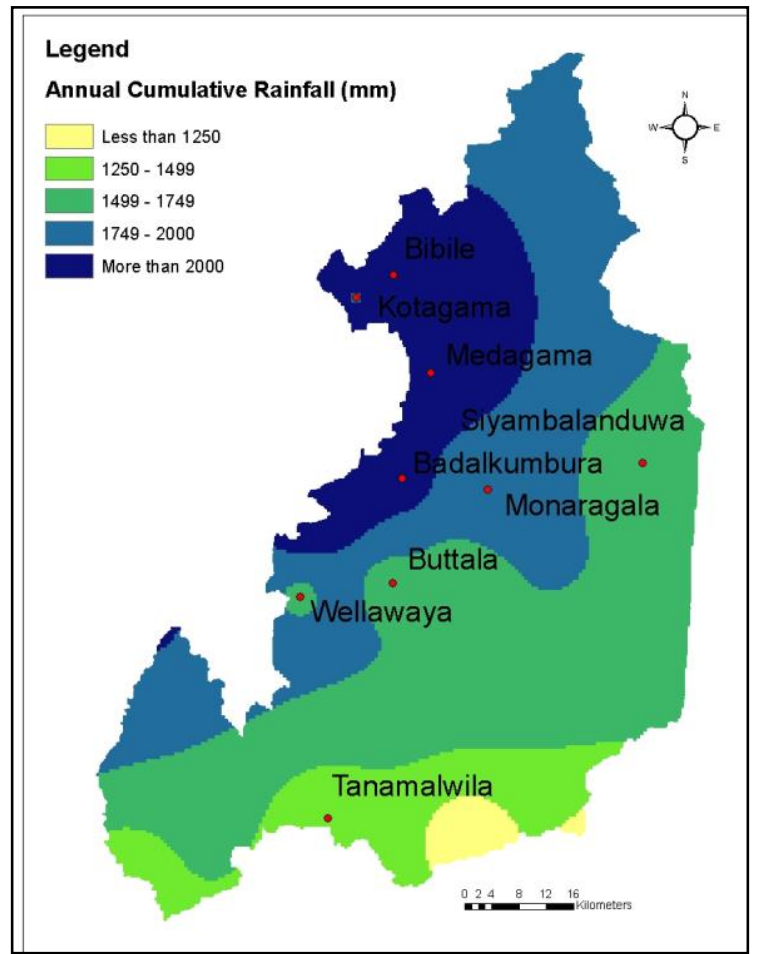

Figure 2: Spatial distribution of the mean annual rainfall

March to August and April to September depicted similar pattern of distribution. During these periods, areas receiving less than $500 \mathrm{~mm}$ in consecutive six months spread towards the northern part of the district along the eastern boundary. If rubber is to be cultivated in these areas much emphasis should be given to the above finding. Special consideration should be given to establish moisture conservation practices for rubber to strive well under these dry conditions. Further it indicated that current rubber-growing areas are not affected by this condition (less than 500 $\mathrm{mm}$ in six consecutive months). The spatial distribution of cumulative rainfall from April to September is presented in Figure 4.

\section{Temperature}

The ideal mean annual temperature for the growth of rubber should be within the range of $23^{\circ} \mathrm{C}$ to $28^{\circ} \mathrm{C}$ and temperature should not fall below $20^{\circ} \mathrm{C}$ for more than few weeks (Yogaratnam, 2001). Very high temperatures exceeding $30^{\circ} \mathrm{C}$ over a prolonged period can adversely affect the physiological processes of the rubber plant. Results revealed that $97 \%$ of the land extent in the Moneragala district has a mean annual temperature between $23^{\circ} \mathrm{C}$ to $27^{\circ} \mathrm{C}$, which is the desirable range for rubber. 


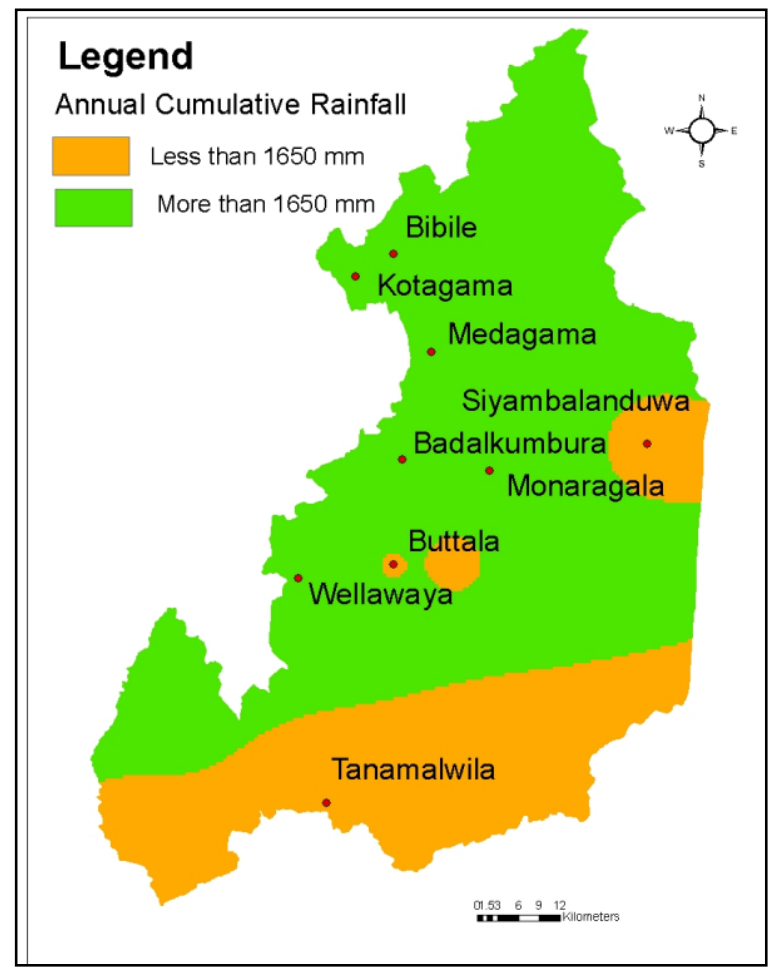

\section{Figure 3: Spatial distribution of the minimum requirement of rainfall for rubber cultivation}

The maximum annual mean temperature of the Monaragala district varied from $26^{\circ} \mathrm{C}$ to $33^{\circ} \mathrm{C}$, which is well within the desirable temperature range. Minimum temperatures in some of the areas in the district fall below $20^{\circ} \mathrm{C}$. It is reported that minimum temperatures less than $20^{\circ} \mathrm{C}$ will retard the growth of rubber and also encourages disease incidence (Yogaratnum, 2001).

\section{Elevation}

Elevation plays a vital role in growth and development of Rubber plants. Yogaratnam (2001) reported that an elevation below $200 \mathrm{~m}$ above mean sea level (amsl) is suitable for growth of rubber. Further it is stated that an increase of $200 \mathrm{~m}$ will delay in achieving the tappable girth by 3 to 6 months. Moreover, it is recommended by the Rubber Research Institute of Sri Lanka not to plant rubber above $600 \mathrm{~m}$ amsl. This is mainly because rubber tree can succumbed to fungal diseases which result in decline of yield significantly. 


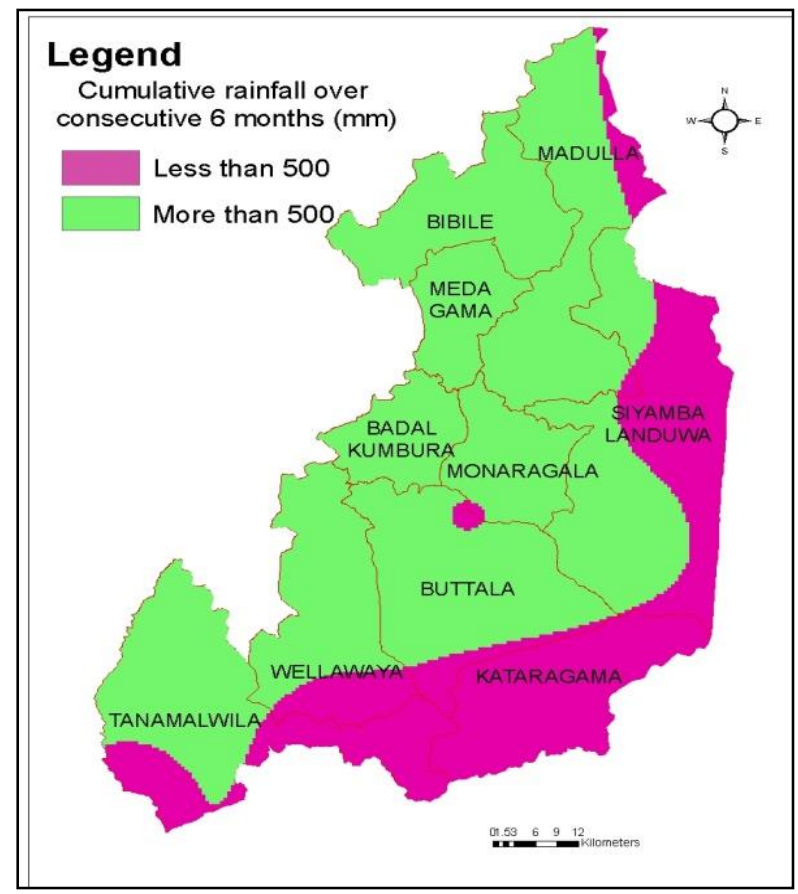

Figure 4: Analysis of cumulative rainfall (April to September)

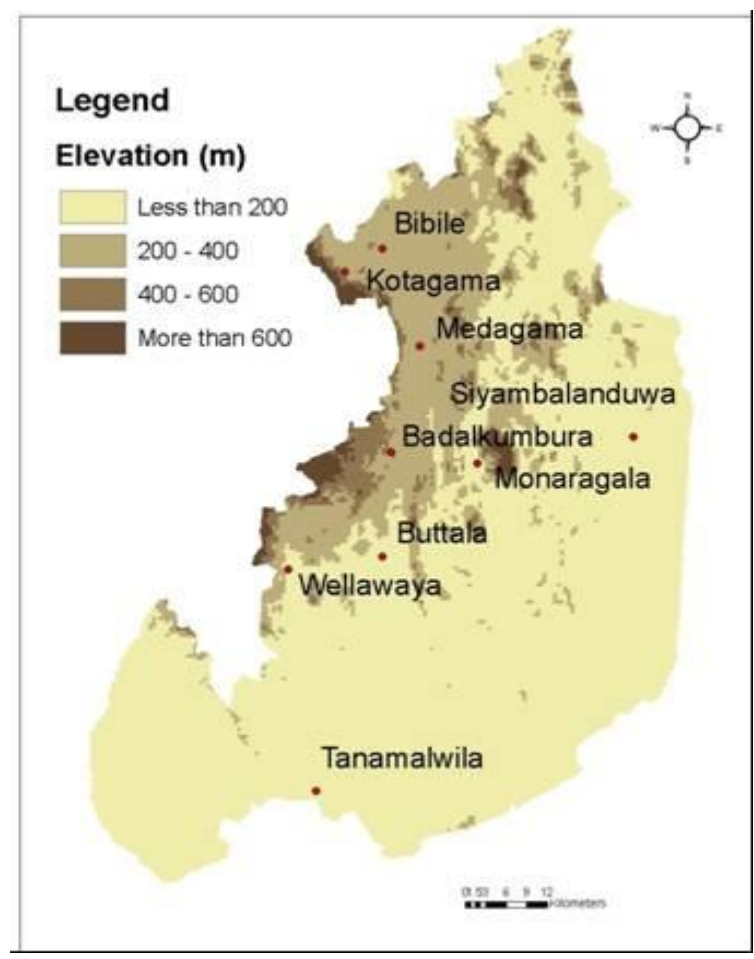

Figure 5: The elevation map of the Moneragala District 
The extents under main categories of elevation in Moneragala district are given in the Table 5 and the elevation map of the Moneragala district is depicted in Figure 5.

Table 5: Elevation classes in the Moneragala District

\begin{tabular}{lc}
\hline \multicolumn{1}{c}{$\begin{array}{c}\text { Elevation Classes } \\
\text { (Above Mean Sea LLevel) }\end{array}$} & Percentage \\
\hline Less than $200 \mathrm{~m}$ & 67 \\
$200-400 \mathrm{~m}$ & 18 \\
$400-600 \mathrm{~m}$ & 5 \\
More than $600 \mathrm{~m}$ & 10 \\
\hline
\end{tabular}

Results revealed that the majority of the land area (67\%) belongs to the category below $200 \mathrm{~m} \mathrm{amsl}$ which is the desirable elevation for rubber. An extent of 128,140 ha is found in between $200 \mathrm{~m}$ to $400 \mathrm{~m}$ and 37,942 ha is found in the range of 400 $\mathrm{m}$ to $600 \mathrm{~m}$. These lands are moderately suitable for the growth of rubber. Elevation above $600 \mathrm{~m}$, which is about 73,095 ha is not suitable for the growth of rubber.

\section{Slope}

Steep slopes have been recognized as a limitation to growth and productivity of rubber. An increase in land slope increases soil erosion under high intensities of rainfall. Most desirable slope for the growth of rubber is less than $20 \%$ where the terrain is flat to undulating and it is not advisable to cultivate rubber where slope exceeds 45\% (Samarappuli, 2001). Analysis of slope classes revealed that most of the lands in the Moneragala district belong to the category of less than $20 \%$ and only $1 \%$ of the land belongs to $>45 \%$ slope (Figure 6 ).

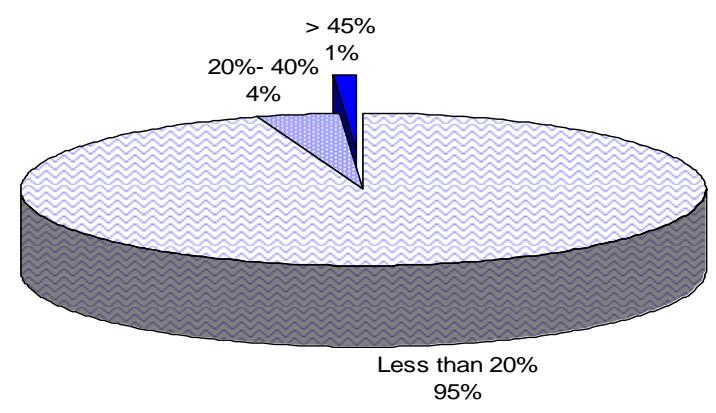

Figure 6: Slope classes in the Monearagala District

The slope classes observed during the survey on land suitability are listed against the selected sites in Table 6. These observations are in agreement with the findings through GIS analysis. In lands with slopes between $20 \%-45 \%$, planting on contours, cutting drains with silt pits and construction of stone terraces are recommended as soil conservation measures to improve retention of soil moisture and nutrients. It 
would also be necessary to establish leguminous ground covers and mulching to reduce surface runoff under these conditions (Samarappuli, 2000).

Table 6: Different slope classes in selected sites

\begin{tabular}{llcc}
\hline \multicolumn{1}{c}{ DS Division } & \multicolumn{1}{c}{ Site } & Slope $\%$ & Status \\
\hline Badalkumbura & Lunugala Kolaniya & $0-5$ & $\mathrm{~S}$ \\
& Karawila & $20-25$ & SCM \\
& Ankada/Gamewela & $20-25$ & SCM \\
\hline Bibile & Radaliedda & $0-10$ & $\mathrm{~S}$ \\
& Bokagonna & $0-10$ & $\mathrm{~S}$ \\
& Badullagammana & $0-8$ & $\mathrm{~S}$ \\
& Yalkumbura & $0-15$ & $\mathrm{~S}$ \\
\hline Wellawaya & Siyambalagune & $0-10$ & $\mathrm{~S}$ \\
\hline Madulla & Dambagalla & $0-5$ & $\mathrm{~S}$ \\
\hline Siyambalanduwa & Pallegama/Helamulla & $0-5$ & $\mathrm{~S}$ \\
\hline Moneragala & Tenagallanda & $0-5$ & $\mathrm{~S}$ \\
\hline Medagama & Ittegala & $10-25$ & $\mathrm{SCM}$ \\
\hline
\end{tabular}

Note: S - Suitable, SCM - Suitable with Corrective Measures

\section{Rockiness}

Most of the rubber lands in Sri Lanka have rock outcrops on the surface. Besides affecting the performance of the rubber tree, rockiness influences the establishment at planting, causing slow establishment and significant casualties at planting. According to the land suitability survey there is no limitation with respect to rockiness in the selected sites of Moneragala (Table 7).

\section{Soil Depth}

The depth of soil profile up to the parent material layer determines the volume of exploitable soil available to the rubber tree. Soil depth is a very critical factor for a tree crop like rubber, which extends its roots far and deep. According to Samarappuli (2001), a rubber land should have a soil depth of at least $100 \mathrm{~cm}$ without any bed rock or compacted hard pan. According to the survey the soil depth of the selected sites is found in the desirable range (Table 7).

\section{Drainage and Water Table}

Poor and impeded drainage and stagnation of water on the soil surface after rain can be harmful to rubber especially during the early stages of life. Water table should be at least $100 \mathrm{~cm}$ to sustain optimum productivity of rubber (Samarappuli, 2001). Water tables less than $100 \mathrm{~cm}$ were not observed in any of the locations (Table 7). 
Table 7: Status of rockiness, soil depth, water table and drainage in some selected sites of Moneragala district

\begin{tabular}{llcccc}
\hline \multicolumn{1}{c}{ DS Division } & \multicolumn{1}{c}{ Site } & $\begin{array}{c}\text { Rockiness } \\
\mathbf{\%}\end{array}$ & $\begin{array}{c}\text { Soil } \\
\text { depth } \\
(\mathbf{c m})\end{array}$ & $\begin{array}{c}\text { Water } \\
\text { table } \\
(\mathbf{c m})\end{array}$ & $\begin{array}{c}\text { Drainage } \\
\text { status }\end{array}$ \\
\hline Badalkumbura & Lunugala Kolaniya & $<50$ & $>150$ & $>130$ & $\mathrm{~S}$ \\
& Karawila & $<50$ & $>150$ & $>150$ & $\mathrm{~S}$ \\
& Ankada/Gamewela & $<50$ & $>150$ & $>150$ & $\mathrm{~S}$ \\
\hline Bibile & Radaliedda & $<50$ & $>150$ & $>150$ & $\mathrm{~S}$ \\
& Bokagonna & $<50$ & $>110$ & $>110$ & $\mathrm{~S}$ \\
& Badullagammana & $<50$ & $>110$ & $>110$ & $\mathrm{~S}$ \\
& Yalkumbura & $<50$ & $>110$ & $>110$ & $\mathrm{~S}$ \\
\hline Wellawaya & Siyambalagune & $<50$ & $>150$ & $>150$ & $\mathrm{~S}$ \\
\hline Madulla & Dambagalla & $<50$ & $>150$ & $>100$ & $\mathrm{~S}$ \\
\hline Siyambalanduwa & Pallegama/Helamulla & $<50$ & $>200$ & $>150$ & $\mathrm{~S}$ \\
\hline Moneragala & Tenagallanda & $<50$ & $>100$ & $>150$ & $\mathrm{~S}$ \\
\hline Medagama & Ittegala & $<50$ & $>100$ & $>150$ & $\mathrm{~S}$ \\
\hline
\end{tabular}

Note: S-Satisfactory

\section{Soil Texture}

Better growth and establishment of rubber are obtained on clayey than sandy soils. This is expected since the inherent physical and chemical characteristics of clay give it the capacity to retain nutrients and water. When water is limiting, establishment rate of young plants at planting, growth of young plants and yield of rubber can also be lower on sandy soils compared to the clayey soils. Soil texture with sufficient clay, preferably a minimum amount of $35 \%$ to retain adequate moisture and nutrients and about 30-50\% sand to allow the for expression of good physical soil properties like aeration and drainage can be considered as desirable for successful rubber cultivation (Samarappuli, 2001). According to the land suitability survey the clay content in all the sites is lower than the minimum amount $(35 \%)$ (Table 8). Hence, proper attention is needed to improve moisture conservation capacities of these soils.

\section{Soil pH}

Rubber generally grows well in acid soils in Sri Lanka. However, extreme acidic conditions are not favourable for good performance of rubber. Stunted growth conditions are observed under extreme acidic conditions of rubber (Samarappuli, 2001). The effect of soil $\mathrm{pH}$ on plant growth is partly through its effects on root 
functions and on soil properties. Soil $\mathrm{pH}$ between 4 to 6 is considered optimum for successful cultivation of rubber. Hence, the observed $\mathrm{pH}$ levels in the selected sites are well within the desirable range as given in Table 9 .

Table 8: Status of soil texture in some selected sites of Moneragala district

\begin{tabular}{llcccc}
\hline \multicolumn{1}{c}{ DS Division } & \multicolumn{1}{c}{ Site } & $\begin{array}{c}\text { Sand } \\
\mathbf{\%}\end{array}$ & $\begin{array}{c}\text { Silt } \\
\mathbf{\%}\end{array}$ & $\begin{array}{c}\text { Clay } \\
\mathbf{\%}\end{array}$ & $\begin{array}{c}\text { Soil } \\
\text { texture }\end{array}$ \\
\hline Badalkumbura & Lunugala Kolaniya & 69 & 18 & 13 & SL \\
& Karawila & 61 & 22 & 17 & SL \\
& Ankada/Gamewela & 55 & 23 & 22 & SCL \\
\hline Bibile & Radaliedda & 71 & 11 & 18 & SL \\
& Bokagonna & 68 & 14 & 18 & SL \\
& Badullagammana & 70 & 15 & 15 & SL \\
& Yalkumbura & 58 & 17 & 25 & SCL \\
\hline Wellawaya & Siyambalagune & 75 & 14 & 11 & SL \\
\hline Madulla & Dambagalla & 75 & 11 & 14 & SL \\
\hline Siyambalanduwa & Pallegama/Helamulla & 79 & 11 & 10 & SL \\
\hline Moneragala & Tenagallanda & 76 & 4 & 20 & SCL \\
\hline Medagama & Ittegala & 66 & 15 & 19 & SL \\
\hline Note: SL-Sandy Loan & & &
\end{tabular}

Note: SL-Sandy Loam, SCL-Sandy Clay Loam

\section{Soil Organic Carbon}

It is known that rubber plantations can undergo a very effective self sustaining recycling system where the soil organic matter content (OMC) maintained, although the tropical soils in Sri Lanka contain relatively low amounts of organic matter. Soil OMC less than $2 \%$ is considered as limiting which needs appropriate soil management practices. The observed OMC in the selected sites were found in the limiting range (Table 9) and hence an integrated approach including proper organic matter/crop residue management need to be adopted as a corrective measure.

\section{Conclusion}

The available information on lands in Moneragala district suggests that the Moneragala Rubber Development Project will not face any difficulty in finding suitable lands for rubber cultivation. Further, to achieve the targets in rubber cultivation, there will be no threat to natural forests since there is enough land under shrub jungles, chena and grasslands. 
Table 9: Status of soil pH, organic carbon and bulk density in some selected sites

\begin{tabular}{llcc}
\hline \multicolumn{1}{c}{ DS Division } & \multicolumn{1}{c}{ Site } & Soil pH & $\begin{array}{c}\text { Organic Carbon } \\
\text { \% }\end{array}$ \\
\hline Badalkumbura & Lunugala Kolaniya & $5.1-5.8$ & $0.70-1.00$ \\
& Karawila & $5.7-6.1$ & $1.00-1.40$ \\
& Ankada/Gamewela & $4.5-5.6$ & $1.10-1.90$ \\
Bibile & Radaliedda & $5.2-5.9$ & 1.00 \\
& Bokagonna & $5.3-5.8$ & $1.00-1.15$ \\
& Badullagammana & $5.1-5.8$ & $1.00-1.20$ \\
Wellawaya & Yalkumbura & $5.1-5.7$ & $1.05-1.40$ \\
Madulla & Siyambalagune & $4.8-6.5$ & $0.60-1.30$ \\
Siyambalanduwa & Pallegama/Helamulla & $6.5-6.6$ & $0.9-1.10$ \\
Moneragala & Tenagallanda & $6.1-6.3$ & $0.5-0.9$ \\
Medagama & Ittegala & $5.6-6.1$ & 1.00 \\
\hline
\end{tabular}

With respect to rainfall, the current rubber growing areas are suitable for rubber planting. Some DS divisions, viz. Kataragama, Tanamalwila and Siyambalanduwa are relatively drier and therefore, when expanding rubber cultivation to Southern and Eastern boundaries of the district, special consideration should be given to establish moisture conservation practices for rubber to thrive well under dry conditions. Results revealed that $97 \%$ of the land extent in the Moneragala district has a mean annual temperature between $23^{\circ} \mathrm{C}$ to $27^{\circ} \mathrm{C}$, which is the desirable range for rubber. The maximum annual mean temperature of the Monaragala district varied from 26 to $33^{\circ} \mathrm{C}$, which is well within the desirable temperature range. Minimum temperatures in some of the areas in the district fall below $20^{\circ} \mathrm{C}$.

Results revealed that the majority of the land area (67\%) belongs to the category below $200 \mathrm{~m}$ amsl. An extent of 128,140 ha is found in between $200 \mathrm{~m}$ to $400 \mathrm{~m}$ and $37,942 \mathrm{ha}$ is found in the range of $400 \mathrm{~m}$ to $600 \mathrm{~m}$. These lands are moderately suitable for the growth of rubber. Elevation above $600 \mathrm{~m}$ (73095 ha) is not suitable for the growth of rubber. Analysis of slope classes revealed that most of the lands in the Moneragala district belong to the category of less than $20 \%$ which is desirable and only $1 \%$ of the land belongs to $>45 \%$ slope.

According to the land suitability survey there is no limitation with respect to rockiness in the selected sites of Moneragala and Badulla districts. Water tables less than $100 \mathrm{~cm}$ were not observed in any of the locations suggesting no limitation in this regard. Drainage is also reported to be satisfactory in the selected sites. The soil 
depth of the selected sites is found in the desirable range $(>1 \mathrm{~m})$. The clay content in all the sites is lower than the minimum amount (35\%). Hence, proper attention is needed to improve moisture conservation capacities of these soils. The observed $\mathrm{pH}$ levels in the selected sites are well within the desirable range (4 to 6). The observed organic matter content (OMC) in the selected sites were found in the limiting range and hence and integrated approach including the proper organic matter/crop residue management need to be adopted as a corrective measure.The study identified the available lands (barren lands, grasslands, shrub lands and under-utilized lands through GIS approach and nearly 6\% (34,752 ha) of the identified land can be categorized under most suitable lands.

\section{References}

Land Use and Planning Division (2003). "Identification of lands for rubber cultivation in Moneragala district”. Land Use Planning Divission, Moneragala.

Samarappuli, L. (2000). "Developments in soil conservation systems in rubber plantations" Jl. of the Nat. Inst. of plantation mgt., 16(2): 33-42.

Samarappuli, L. (2001). "Land and soil requirement for optimum growth and productivity of rubber under Sri Lankan conditions" Bull. of the Rubber Research Institute of Sri Lanka, 43: 35-42.

Yogaratnam, N. (2001). "Land suitability evaluation, selection and soil conservation". In: Handbook of Rubber, 1: 1-11 (Eds. Tillekeratne , L. M. K and Nugawela , A.), Rubber Research Institute of Sri Lanka, Agalawatta, Sri Lanka. 